\title{
IN VITRO TOXICITY OF CYPERMETHRIN AND DELTAMETHRIN ON THE CATTLE TICK Rhipicephalus microplus
}

\author{
TOXICIDADE IN VITRO DA CIPERMETRINA E DELTAMETRINA SOBRE O CARRAPATO-DO- \\ BOI, Rhipicephalus microplus
}

\author{
I. CHARLIE-SILVA ${ }^{1}$, L. M. SOUZA ${ }^{2 *}$, M. A. A. BELO ${ }^{1,2}$, A. C. MORAES ${ }^{1}$, \\ E. J. R. PRADO ${ }^{1}$, M. B. MOLENTO ${ }^{3}$, M. MARCHIORI-FILHO ${ }^{4}$
}

\begin{abstract}
SUMMARY
The objective of this work was to evaluate the efficacy of cypermethrin $15 \%$ and deltamethrin $25 \%$ of the cattle tick Rhipicephalus microplus, using immersion test of engorged females (ITEF) and impregnated Pasteur pipette (PIPT). The following dilutions were used: $\mathrm{T} 1=1 / 1000 \mathrm{~mL}(\mathrm{v} / \mathrm{v}), \mathrm{T} 2=2 / 1000 \mathrm{~mL}, \mathrm{~T} 3=4 / 1000 \mathrm{~mL}$ and T4 $=8 / 1000 \mathrm{~mL}$, respecting the dosages prescribed by the manufacturers for both pyrethroids. The Experiment I used adult females, and the acaricidal efficacy was tested on engorged females, that were collected separately from ten dairy herds in the Descalvado region, SP. The data revealed that the efficacy for cypermethrin ranged from 0.0 to $95.9 \%$ and for deltamethrin was $34.4 \%$ to $99.2 \%$. We have observed that the efficacy of deltamethrin and cypermethrin was higher than $95 \%$, in only four farms. Treatment with cypermethrin at $8 / 1000 \mathrm{~mL}$ dilution resulted in $100 \%$ of efficacy against larvae after 120 minutes. Deltamethrin at $8 / 1000 \mathrm{~mL}$ dilution resulted in $100 \%$ of larvae exhibiting paralysis after 60 minutes. The data revealed that the efficacy for cypermethrin ranged from $0.0 \%$ to $95.9 \%$ and for deltamethrin was $34.4 \%$ to $99.2 \%$. We have observed that the efficacy of deltamethrin and cypermethrin was higher than $95 \%$, in only four farms. The experiment II used the PIPT against larvae and the efficacy of the same products was checked at 5, 10, 20, 30, 60, 120, 360 and 720 min post-treatment. Treatment with cypermethrin at $8 / 1000 \mathrm{~mL}$ dilution, resulted in $100 \%$ efficacy against larvae after $60 \mathrm{~min}$ and $100 \%$ of larvae treated with deltamethrin presented paralysis $30 \mathrm{~min}$ post-treatment with the dilution of $8 / 1000 \mathrm{~mL}$. Although both pyrethroids were $100 \%$ efficacious against larvae, the low percentage of adulticidal efficacy confirms the existence of resistant strains of this tick species. However, in four herds cypermethrin and deltamethrin were effective in controlling R. microplus, reinforcing the importance of performing immersion test of engorged females before prescribing treatments to dairy cattle, not only in this region but to the entire country.
\end{abstract}

KEY-WORDS: resistance, ixodids, Pasteur pipette test, immersion test of engorge females.

\section{RESUMO}

O objetivo deste trabalho foi avaliar a eficácia de cipermetrina $15 \%$ e de deltametrina $25 \%$, contra cepas do carrapato-do-boi Rhipicephalus microplus, utilizando as técnicas de imersão de fêmeas ingurgitadas (TIFI) e da pipeta Pasteur impregnada (TPPI). Respeitando-se as dosagens prescritas pelos fabricantes para ambos os fármacos, foram utilizadas as seguintes diluições T1: 1/1000 mL (v/v), T2=2/1000 mL, T3 = 4/1000 mL, T4 = 8/1000 mL. No experimento I, o TIFI foi utilizado em fêmeas adultas ingurgitadas, colhidas separadamente em dez propriedades na bacia leiteira da região de Descalvado, SP. Os resultados revelaram que eficácia da cipermetrina variou entre $0,0 \%$ e $95,9 \%$ e para a deltametrina foi de $34,4 \%$ a $99,2 \%$. Observou-se que a eficácia $>95 \%$ da deltametrina e cipermetrina sobre o carrapato, ocorreu em apenas quatro propriedades. No experimento II, com larvas, o TPPI foi utilizado para determinar a eficácia larvicida dos mesmos produtos por meio da perda de motilidade das larvas, nos tempos 5, 10, 20, 30, 60, 120, 360 e 720 minutos pós-tratamento. O tratamento com cipermetrina na diluição de $8 / 1000 \mathrm{~mL}$ resultou em $100 \%$ de eficácia contra larvas após 120 minutos. A deltametrina causou paralisia de $100 \%$ das larvas após 60 minutos na diluição de 8/1000 mL. Apesar de ambos os piretróides apresentarem $100 \%$ de eficácia contra larvas, o baixo percentual de eficácia adulticida comprovou a existência de cepas resistentes destes ácaros. Contudo, em quatro rebanhos, a cipermetrina e a deltametrina, se mostraram eficazes no controle de adultos de $R$. microplus, reforçando a importância de se realizar o teste de biocarrapaticidograma para determinar a eficácia de produtos, antes de prescrever tratamentos em rebanhos leiteiros, não somente nesta região, porém em todo o País.

PALAVRAS-CHAVE: resistência, ixodídeos, Teste da pipeta de Pasteur, Teste de imersão de teleógina

\footnotetext{
${ }^{1}$ Departamento de Medicina Veterinária Preventiva, FCAV - UNESP, Campus de Jaboticabal, São Paulo, Brasil.

${ }^{2}$ Universidade Brasil, Campus de Descalvado, São Paulo, Brasil. Autor correspondente: Avenida Hilário da Silva Passos, 950. Parque Universitário, Descalvado/SP, Brasil, CEP 13690-000.Email: lucianomelos@gmail.com

${ }^{3}$ Departamento de Medicina Veterinária, Laboratório de Doenças Parasitárias, Universidade Federal do Paraná, UFPR. Curitiba, Paraná, Brasil. ${ }^{4}$ UCB Vet Saúde Animal. Jaboticabal, Brasil.
} 


\section{INTRODUCTION}

A subject of concern and losses related to animal production, tick parasitism has always been a great participation in the transmission of etiological agents, and important zoonotic diseases (DE LA FUENTE \& KOCAN, 2003). The losses described in the scientific and technical literature involve weight loss, decreased milk production, blood spoliation and transmission of hemoparasites, such as Anaplasma marginale, Babesia bovis and B. bigemina. Rhipicephalus microplus is the acarina species with the greatest geographical distribution and economic importance for cattle producing countries in tropical and subtropical areas of the world (ANDREOTTI, 2010; GRISI et al., 2014).

The constant use of acaricidal compounds in infested bovine herds, mostly applied by people without adequate technical knowledge, leads to inadequate administrations, even neglecting the treatment grace period, thus compromising human health, consuming animal by-products, as well as animal health (MORAES et al., 2015). These errors in sanitary management have favored the selection of resistant tick populations and, consequently, multiplying the frequency of treatments, further increasing the amount of residues in meat, milk and environment (GRAF et al., 2004). Numerous strategies have been conducted to control the tick, such as use of pasture rotation (VERÍSSIMO, 2013), selective treatment (MOLENTO et al., 2013), strategic control (FURLONG et al., 2003), entomopathogenic fungi (BASSO et al., 2005), phytotherapy (SILVA et al., 2010) and vaccines (CARVALHO et al., 2008).

In Brazil, studies to monitor the $R$. microplus susceptibility to acaricides, as well as their correct use, are necessary and urgent, since several antiparasitic compounds are administered indiscriminately in different forms and dosages in cattle and infested environments, resulting in ineffectiveness of acaricides, economic losses to breeders, as well as intoxication of animals and humans with drug residues (SOARES et al., 2009; BELO et al., 2012; SOUZA et al., 2017). $R$. microplus resistance to cypermethrin and deltamethrin can be verified in a large number of publications all over the world (SOUZA et al., 2008; ANDREOTTI et al., 2011). In this context, the present study aimed to evaluate the efficacy of cypermethrin and deltamethrin in adults and larvae of $R$. microplus from farms belonging to the municipality of Descalvado, São Paulo State, Brazil.

\section{MATERIAL AND METHODS}

\section{Experiment I - Immersion Test of Engorged Females (ITEF)}

The collection of engorged females was carried out in 10 properties belonging to the dairy basin from Descalvado region (S 21 54 '14 ", W 47 37' 12"), located in the State of São Paulo, Brazil. The females were placed in cardboard boxes identified and transported to the Laboratory of Parasitology at the
Brazil University. To evaluate the in vitro susceptibility, individual tests were done for each property, using the technique proposed by Drummond (1973). Initially, the females were washed in running water, drained with absorbent paper and divided into groups of 10 ticks each, in order of decreasing size to obtain more homogeneous weights between groups. Four replicates with 10 engorged females were immersed in cypermethrin solutions containing $15 \%$ $1 / 500 \mathrm{~mL}(\mathrm{v} / \mathrm{v})$ (Cypermetril $^{\circledR}$, UCBVET Animal Health) and 25\% deltamethrin $0.5 \mathrm{~mL} / 500 \mathrm{~L}$ (v/v) (Butox $^{\circledR}$, MSD Animal Health) diluted in distilled water, respecting the dilutions indicated by the manufacturers, and the control group was immersed only in distilled water. The larvae hatchability was evaluated by percentage estimation in relation to those that did not hatch. The acaracide effectiveness calculation was carried out from the data of tick weight, eggs weight and percentage of hatching, according to Drummond (1973).

\section{Reproductive Efficiency}

$$
R E=\frac{\text { Eggweight } X(\% \text { of hatch }) X\left(20.000^{*}\right)}{\text { Engorged Females weight }}
$$

*Estimated number of eggs in $1 \mathrm{~g}$ of $R$. microplus eggs.

\section{Product Efficacy} $P E=\frac{(R E \text { control group }-R E \text { treated group })}{R E \text { control group }} \times 100$

\section{Experiment II - Pasteur impregnated pipette technique (PIPT)}

In order to evaluate the loss of motility on contact with acaricidal therapeutic compounds, the in vitro method with Pasteur pipette, recommended by Barci and Nogueira (2006), was conducted. Larvae were removed from the better hatchability (> 90\%) compared to commercial products described above. Prior to the challenge, the pipettes were impregnated by immersion in solution containing the acaricides, which were diluted in distilled water. The products, cypermethrin and deltamethrin were tested in the following dilutions: $\mathrm{T} 1=1 / 1000 \mathrm{~mL}(\mathrm{v} / \mathrm{v}), \mathrm{T} 2=2 / 1000$ $\mathrm{mL}(\mathrm{v} / \mathrm{v}), \mathrm{T} 3=4 / 1000 \mathrm{~mL}(\mathrm{v} / \mathrm{v}), \mathrm{T} 4=8 / 1000 \mathrm{~mL}(\mathrm{v} / \mathrm{v})$, in addition to the control group were tested containing only distilled water. After drying, the larvae were selected according to their motility, being vacuum aspirated into the pipettes and kept in a greenhouse with biochemical oxygen demand (BOD) controlled with incubator $27^{\circ} \mathrm{C}$ to $28^{\circ} \mathrm{C}$ temperature and relative humidity (RH) between $80-90 \%$. In each treatment, nine replicates containing 20 larvae/treatment were performed. The larvae were observed at 5, 10, 20, 30, $60,120,360$ and 720 min post-treatment. After this 
period, all pipettes were placed back into the BOD to complete the observations until the fifth day of observation.

\section{Statistical analysis}

Data relating to loss of larvae motility were analyzed in a One-Way ANOVA $(\alpha=0.05)$. The Bartlet test $(\mathrm{P}=>0.05)$ and the Shapiro-Wilk test $(\mathrm{P}=>$ $0.05)$ were used to establish the statistical hypothesis of homocedasticity and normality of the internally standardized residues, respectively. The Tukey test $(\mathrm{P}<0.05)$ was used for comparisons between means. All statistical analyzes were processed in the $\mathrm{SAS}^{\circledR}$ software (Statistical Analysis System), version 9.3.

\section{RESULTS AND DISCUSSION}

The initial weight of engorged females was $2.17 \mathrm{~g}$ with range of variation between 2,078 to $2.34 \mathrm{~g}$. The results of hatchability and reproductive efficiency are shown in Figure 1. It was possible to observe the high pharmacological activity of the treatment with deltamethrin, determined by the low larvae hatchability $(36.6 \%)$. On the other hand, the reproductive efficiency was more pronounced for the cypermethrin group.
According to Brazilian Ministry of Agriculture Livestock and Supply regulated by the Portaria 48, published May 12 of 1997 (BRASIL, 1997), all formulations tested presented therapeutic efficacy percentages higher than $95 \%$ in at least four tested properties, which makes it possible to affirm and to recommend the (ITEF) test as a technical tool to diagnose the pharmacological compounds efficacy, as well as to allow the prospection of acaricides suitable in programs for bovine tick control.

Variations in the percentages of susceptibility to cypermethrin and deltamethrin treatments in different farms were observed, which can be explained by the distinct tick populations in each property. Similar values were found by Camillo et al. (2009) testing cypermethrin in 29 properties in the Rio Grande do Sul state, with an efficacy index between $0 \%$ to $100 \%$, and low efficacy of deltamethrin in the state of Minas Gerais was described by Carneiro et al. (2015). In addition, several studies have already determined the reduction of the acaricidal efficacy of deltamethrin and cypermethrin in dairy herds (FARIA et al., 2008; ANDREOTTI et al., 2011; VEIGA et al., 2014).
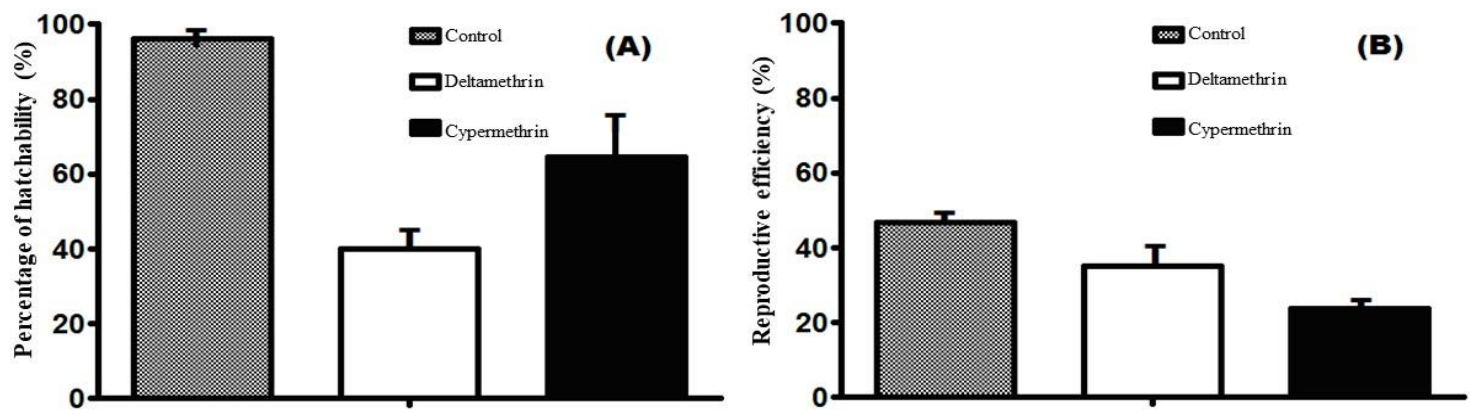

Figure 1 - (A) Percent larvae hatchability and (B) Reproductive efficiency of $R$. microplus after treatment with deltamethrin or cypermethrin in engorged females from dairy herds, Descalvado basin, SP, Brazil.

The results relating to toxic effect from tested drugs on $R$. microplus larvae can be visualized in Figure 2 (A, B, C and D). Regardless of the time, mortality of $100 \%$ of larvae $360 \mathrm{~min}$ post-treatment was observed for all the experimental groups when compared to control group. This fact allows to affirm the larvicidal efficacy for both pyrethroids. The larvae from control group remained active until the fifth experimental day (data not shown). The technique used in the present study is different from the usual methodologies, and was specially developed for larval motility studies. This technique facilitates the determination of the dose-response effect, which was faster on larvae treated with deltamethrin than with cypermethrin. In this context, the cypermethrin effect on larvae showed $100 \%$ of loss motility 120 minutes after treatment only when treated with 8 times the recommended dose; the other concentrations showed similar effect 360 minutes after the treatment. While in the study of deltamethrin $100 \%$ of larval paralysis was observed after 60 minutes of treatment when submitted to concentrations of 4 to 8 times of the therapeutic dose and 120 minutes after the treatment, for larvae treated with half and 2 times the dose. After 120 minutes of treatment, the efficacy of deltamethrin was observed at all concentrations (Figure 2). 

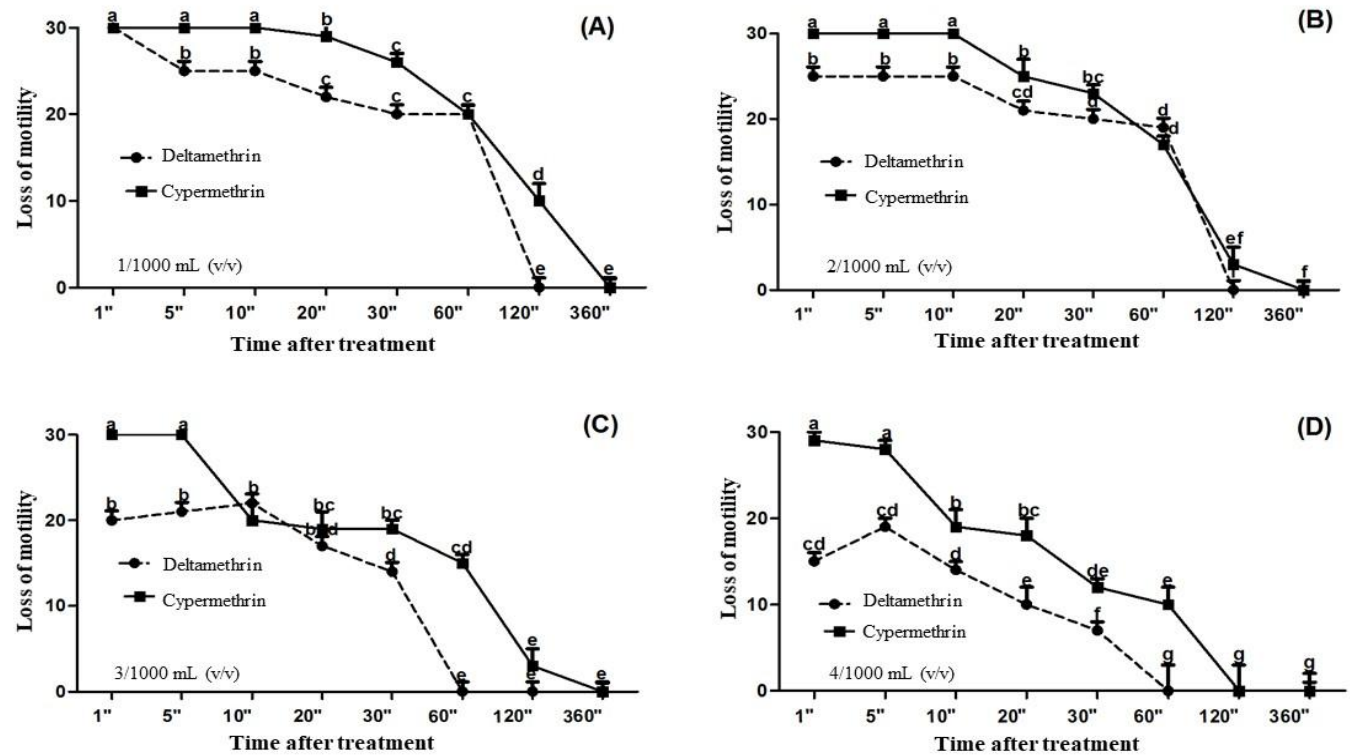

Figure 2 - Mean (standard deviation) and one-way ANOVA analysis of in vitro larval toxicity of $R$. microplus against different concentrations of cypermethrin and deltamethrin (A) $1 / 1000 \mathrm{~mL}$ (v/v), (B) 2/1000 mL, (C) 4/1000 mL, (D) 8/1000 mL.

These findings reveal that both pyrethroids presented efficacy. However, the most significant effect of paralysis was observed in $R$. microplus larvae exposed to deltamethrin. Similar values were found by Fernandes et al. (2001) who studied toxicological effects in $R$. sanguineus, such as incoordination, knock-down and paralysis followed by death. However, the lethal capacity of deltamethrin after $30 \mathrm{~h}$ was low, with a mean mortality of $34 \% ; 40.2 \% ; 46 \%$ and $57.6 \%$ for the dosages of $0.5 ; 1.0 ; 2.0$ and 3.0 (mL), respectively. However, Mendes et al. (2007) observed superior efficacy of deltamethrin when compared to cypermethrin in adult immersion studies $R$. microplus. Despite the differences in the larvicidal effect, during the observational times, $100 \%$ efficacy was obtained for all products. These results showed that all $R$. microplus larvae presented mortality 360 minutes after treatment.

Soares et al. (2009) demonstrated the antiparasitic efficacy of pyrethroids against $R$. microplus mainly when potentiated by the synergistic action of piperonyl butoxide. These synthetic chemical compounds alter the permeability of sodium channels in the parasite axon cell membrane, compromising the action potential propagation and the nerve impulse transmission, leaving the axonal membrane permanently depolarized, thus paralyzing the parasite organism (BELO et al., 2012). This pharmacological activity attributed to pyrethroids justifies the effects observed in $R$. microplus larvae with initial loss of motility, followed by death of these ixodids.

\section{CONCLUSION}

The results revealed the presence of $R$. microplus resistant strains to cypermethrin and deltamethrin treatment in Descalvado, central region of the State of São Paulo. Toxic effect of deltamethrin on
$R$. microplus larvae motility was faster than observed on larvae exposed to cypermethrin. However, $100 \%$ of efficacy was observed for both pyrethroids at all studied dilutions on $R$. microplus larvae. These data reinforce the importance of performing the immersion test of engorged females to determine the efficacy of products before prescribing treatments in dairy herds, not only in this region, but throughout the country.

\section{REFERENCES}

ANDREOTTI, R.; GUERREIRO F. D.; SOARES, M. A.; BARROS, J. C.; MILLER, R. J.; LEÓN, A. P. Acaricide resistance of Rhipicephalus (Boophilus) microplus in State of Mato Grosso do Sul, Brazil. Revista Brasileira de Parasitologia Veterinária, Jaboticabal, v.20, n.2, p.127-133. 2011.

ANDREOTTI, R. Situação atual da resistência do carrapato do boi Rhipicephalus (Boophilus) microplus aos acaricidas no Brasil. Campo Grande, MS: Embrapa Gado de Leite, 2010. 36 p. Embrapa Gado de Leite. Circular Técnica, 180.

BARCI, L. A. G.; ALMEIDA, J. E. M.; NOGUEIRA, A. H. C.; ZAPPELINI, L. O.; PRADO, A. P. Seleção de isolados do fungo entomopatogênico Beauveria bassiana (Ascomycetes: Clavicipitaceae) para o controle de Rhipicephalus (Boophilus) microplus (Acari: Ixodidae) Revista Brasileira Parasitologia Veteterianria, Jaboticabal, v. 18 supl.1, p.7-13, 2009.

BARCI, L. A. G.; NOGUEIRA, A. H. C. Método para avaliação de mortalidade de larvas de Boophilus microplus (Canestrini, 1887) submetidas a tratamentos com produtos carrapaticidas. Arquivos do Instituto Biologico, São Paulo, v. 73, n. 1, p. 105109, 2006. 
BASSO, L. M. S.; MONTEIRO, A. C.; BELO, M. A. A. ; SOARES, V. E.; GARCIA, M. V.; MOCHI, D. A. Controle de larvas de Boophilus microplus por Metarhizium anisopliae em pastagens infestadas artificialmente. Pesquisa Agropecuária Brasileira, Brasília, v. 40, p. 595-600, 2005.

BELO, M. A. A.; PRADO, E. J. R.; SOARES, V. E.; SOUZA, L. M.; MOTA, F. C. C.; GIAMLORENÇO, T. F.; GÍRIO, T. M. S. Eficácia de diferentes formulações no controle da mosca Haematobia irritans em bovinos naturalmente infestados. Bioscience Journal, Uberlândia, v. 28, p. 245-250, 2012.

BRASIL, Ministério da Agricultura, Pecuária e Abastecimento. Portaria n.48 de 12 de maio de 1997. Regulamento técnico para licenciamento e/ou renovação de licença de produtos antiparasitarios de uso veterinário. Diário Oficial, 16 maio 1997.

BRASIL, Ministério da Agricultura, Pecuária e Abastecimento. Portaria n.90 de 04 de dezembro de 1989. Normas para produção, controle e utilização de produtos antiparasitários. Diário Oficial, 22 jan. 1990, sec. 1 , col. 2 .

CAMILlO, G.; VOGEL, F. F.; SANGIONI, L. A.; CADORE, G. C.; FERRARI, R. Eficiência in vitro de acaricidas sobre carrapatos de bovinos no Estado do Rio Grande do Sul, Brasil. Ciência Rural, Santa Maria, v. 39, n.2, p.490-495, 2009.

CARVALHO, G.; PECONICK, A. P.; MEDEIROS, C. L.; VARGAS, M. I.; PATARROYO, J. H. Imunização com o peptídeo sintético anti-carrapato Rhipicephalus (Boophilus) microplus SBm7462 por vias de mucosa. Revista Brasileira de Parasitologia Veterinária, Jaboticabal, v. 17, supl. 1, p. 9-13, 2008.

CARNEIRO, J. C.; COSTA, E. G. L.; VASCONCELOS, V. O.; OLIVEIRA, N. J. F. Diagnóstico do controle e eficácia de acaricidas para o carrapato bovino no Semiárido do Norte de Minas Gerais. Acta Scientiae Veterinariae, Porto Alegre, v.43, p.1267-1276, 2015.

DE LA FUENTE, J.; KOCAN K. M. Advances in the identification and characterization of protective antigens for recombinant vaccines against tick infestations. Expert Review of Vaccines, London, v. 2, n. 4, p. 583-593, 2003.

DRUMMOND, R.O. Boophilus annulatus and Boophilus microplus: laboratory tests for insecticides. Journal of Economic Entomology, Oxford, v.66, p.130-133, 1973.

FARIAS, N. A.; RUAS, J. L.; SANTOS, T. R. B. Análise da eficácia de acaricidas sobre o carrapato Boophilus microplus, durante a última década, na região sul do Rio Grande do Sul. Ciência Rural, Santa Maria, v.38, n.6, p.1700-1704, 2008.
FERNANDES, F. F. Toxicological effects and resistance to pyrethroids in Boophilus microplus from Goiás, Brazil. Arquivo Brasileiro de Medicina Veterinária e Zootecnia, Belo Horizonte, v.53, n.5, p.538-543, 2001.

FURLONG, J.; MARTINS, J. R. S.; PRATA, M. C. A. Carrapato dos bovinos: controle estratégico nas diferentes regiões brasileiras. Juiz de Fora: Embrapa Gado de Leite, 2003. 5p. Embrapa Gado de Leite. Comunicado Técnico, 36.

GRAF, J. F.; GOGOLEWSKI, J. F.; LEACH-BING, N.; SABATINI, G. A.; MOLENTO, M. B.; BORDIN, E. L.; ARANTES, G. J. Tick control: an industry point of view. Parasitology, Cambridge, v.129, p.427-442, 2004.

GRISI, R.; LEITE, R. C. L.; MARTINS, J. R. S. M.; BARROS, A. T. M.; ANDREOTTI. R.; CANÇADO, P. H. D.; LEÓN, A. A. P.; PEREIRA, J. B.; VILLELA, H. S. Reassessment of the potential economic impact of cattle parasites in Brazil. Brazilian Journal Veterinary Parasitology., Jaboticabal, v. 23, n. 2, p. 150-156. 2014.

MOLENTO, M. B.; FORTES, F. M.; BUZATTI, A.; KLOSTER, F. L.; COIMBRA, E.; SOARES, L. D. Partial selective treatment of Rhipicephalus microplus and breed resistance variation in beef cows in Rio Grande do Sul, Brazil. Veterinary Parasitology, Amsterdam, v. 192, 1-3, p. 234-239, 2013.

MENDES, M. C.; LIMA, C. K. P.; PRADO, A.P. Determinação da frequência de realização de bioensaios para o monitoramento da resistência do carrapato Boophilus microplus (Acari: Ixodidae). Arquivos do Instituto Biológico., São Paulo, v.74, n.2, p.87-93, abr./jun., 2007.

MORAES, A. C.; PRADO, E. J. R.; FARIA, V. P.; GÍRIO, T. M. S. ; MANRIQUE, W. G.; BELO, M. A. A. Clinical safety of dichlorvos $(45 \%)$, cypermethrin $(5 \%)$ and piperonyl butoxide $(25 \%)$ administerd by spray on the skin of cattle. MVZ Cordoba, Cordoba, v. 20, p.4873-4882, 2015.

PEREIRA, M. C.; LABRUNA, M. B.; SZABÓ, M. P. J.; KLAFKE, G. M. Rhipicephalus (Boophilus): biologia, controle e resistência. 1a edição. São Paulo: MedVet Livros, 2008.

SANTOS, T. R. B.; FARIAS, N. A. R.; CUNHAFILHO, N. A.; PAPPEN, F. G.; VAZ JUNIOR, I. S. Studies of the management of the tick Rhipicephalus (Boophilus) microplus in southern Rio Grande do Sul, Brazil. Pesquisa Veterinária Brasileira, Brasília, v.29, n.1, p.65-70, 2009.

SILVA, I. C.; SOUZA, L. M.; BELO, M. A. A.; SOARES, V. E. Larval hatchability from egg masses of Rhipicephalus (Boophilus) microplus treated with different acaricides. In: XIII International Congress of Acarology, Recife / PE, 2010. 
SILVA, J.; SOUZA, L. M.; SILVA, I. C.; SOARES, V. E.; BELO, M. A. A.; TORRENTE, A. C. G.; FARIA, V. P.; MAZZONETTO, F.; CHAGAS, A. C. S. Potencial larvicida do extrato aquoso de Jatropha curcas (Pinhão manso), sobre Rhipicephalus (Boophilus) microplus. In: V Congresso da Sociedade Paulista de Parasitologia, Guarulhos, SP. 2010.

SOARES, V. E.; BELO, M. A.; SOUZA, L. M.; GUIARO, C. R.; BORTOLETTO NETO, O.; GIRIO, T. S. Associação de cipermetrina, diclorvós e butóxido de piperonila contra Rhipicephalus (Boophilus) microplus em bovinos naturalmente infestados. Archives of Veterinary Science, Curitiba, v. 14, p. 18, 2009.
SOUZA, L. M.; BELO, M. A.; SILVA, I. C. Eficácia de diferentes formulações de acaricidas sobre larvas de Rhipicephalus sanguineus (Latreille, 1806) (Acari: Ixodidae) e Rhipicephalus (Boophilus) microplus (Canestrini, 1887) (Acari: Ixodidae). Biotemas, Florianópolis, v. 30, p. 65, 2017.

VEIGA, L. P.; SOUZA, A. P.; BELLATO, V.; SARTOR, A. A.; NUNES, A. P.; CARDOSO, H. M. Resistance to cypermethrin and amitraz in Rhipicephalus (Boophilus) microplus on the Santa Catarina Plateau, Brazil. Revista Brasileira Parasitologia Veteterinária, Jaboticabal, v.21, p.133136, 2012.

VERÍSSIMO, C. J. Controle de carrapatos nas pastagens. Nova Odessa: Instituto de Zootecnia, 99p. 2013 